\title{
FUNGSI PENDEKATAN BIMBINGAN DAN KONSELING
}

\author{
Nasuha \\ Sekolah tinggi Agama Islam (STAI) Darud Dakwah Wal-Irsyad (DDI), Makassar \\ Email : nasuha2801@gmail.com
}

\begin{abstract}
ABSTRAK
Bimbingan dan konseling adalah pelayanan bantuan untuk peserta didik, baik secara perorangan maupun kelompok agar mandiri dan bisa berkembang secara optimal, dalam bimbingan pribadi, sosial, belajar maupun karier melalui berbagai jenis layanan dan kegiatan pendukung berdaarkan norma-norma yang berlaku (SK Mendikbud No. 025/D/1995).
\end{abstract}

\section{Kata Kunci : fungsi Pendidikan, bimbingan, konseling}

\section{A. Pendahuluan}

Pendidikan adalah sebuah aset yang penting di dalam kehidupan berbangsa dan bernegara, karena bagaimana pun tidak ada bangsa yang maju tanpa diiringi pendidikan yang bermutu ${ }^{1}$. Pendidikan yang berkualitas bukan hanya dilihat dari sejauh mana proses pengajarannya, Yusuf (2005: 5) memaparkan ada tiga bidang pendidikan yang harus menjadi perhatian, diantaranya; Bidang administrative dan kepemimpinan, Bidang Intruksional dan kurikuler, dan Bidang pembinaan siswa (Bimbingan dan Konseling). Daam makalah ini akan membahas tentang bimbingan dan konseling.

Pendekatan bimbingan dan konseling bertujuan agar peserta didik dapat menemukan dirinya, mengenal dirinya, dan mampu merencanakan masa depannya. Dalam hal ini, bimbingan dan konseling dapat berfungsi sebagai pemberi pelayanan terhadap anak didik agar masing-masing anak didik bisa berkembang secara maksimal sehingga bisa menjadi pribadi yang mandiri dan $u u^{2}{ }^{2}$. Maka dari itu, layanan bimbingan dan konseling merupakan untuk mengembangkan sejumlah fungsi yang hendak dipenuhi melalui kegiatan bimbingan dan konseling.

\section{B. Pembahasan}

\footnotetext{
${ }^{1}$ Bhakti, C. P. (2015). Bimbingan Dan Konseling Komprehensif: Dari Paradigma Menuju Aksi. Jurnal Fokus Konseling, 1(2), 106-108.)

${ }^{2}$ Handaka, I. B., \& Maulana, C. (2017). Peran Guru Bimbingan Dan Konseling Dalam Implementasi Gerakan Literasi Nasional. In Prosiding Seminar Bimbingan Dan Konseling (Vol. 1, No. 1, pp. 267-268).
} 
Fungsi pendekatan adalah fungsi yang akan menghasilkan pemahaman tentang sesuatu oleh pihak-pihak tertentu sesuai dengan kepentingan pengembangan peserta didik. Fungsi pendekatan yaitu:

1. Pendekatan terhadap peserta didik itu sendiri, terutama oleh peserta didik sendiri, guru pada umumnya, guru pembimbing dan orang tua.

2. Pendekatan terhadap lingkungan peserta didik, termasuk di dalamnya keluarga dan sekolah terutama oleh peserta didik sendiri, guru, orang tua, dan guru pembimbing.

3. Pendekatan tentang lingkungan yang lebih termasuk di dalamnya informasi pendidikan informasi jabatan/pekerjaan dan informasi sosial dan budaya/ nilai-nilai), terutama oleh peserta $\operatorname{didik}^{3}$.

Tujuan utama layanan bimbingan dan konseling di sekolah adalah memberikan dukungan pada pencapaian kematangan kepribadian, keterampilan sosial, kemampuan akademik, dan bermuara pada terbentuknya kematangan karir individual yang diharapkan dapat bermanfaat di masa yang akan datang ${ }^{4}$.

Adapun pendekatan bimbingan dan konseling terbagi menjadi 4 macam yaitu:

\section{Pendekatan kritis}

Adalah usaha bimbingan dan konseling yang di arahkan kepada individu yang mengalami krisis. Tujuan bimbingan dan konseling dengan pendekatan ini untuk mengatasi krisis atau berbagai persoalan yang di alami individu ${ }^{5}$. Pelayanan bimbingan dan konseling dengan pendekatan ini, biasanya dalam praktikny guru bimbingan atau konselor menunggu klien yang datang, seterusnya mereka memberikan bantuan sesuain dengan krisis yang di rasakan oleh klien.

\section{Pendekatan Remedial}

Tujuan bimbingan dan konseling dalam pendekatan ini untuk menghilangkan berbagai kesusahan yang dialami individu. Fokus bimbingan dan konseling dalam pendekatan ini adalah kelamahan-kelemahan individu yang seterusnya berupa untuk

\footnotetext{
${ }^{3}$ Bhakti, C. P. (2015). Bimbingan Dan Konseling Komprehensif: Dari Paradigma Menuju Aksi. Jurnal Fokus Konseling, 1(2), 93-106.

${ }^{4}$ Bhakti, C. P. (2015). Bimbingan Dan Konseling Komprehensif: Dari Paradigma Menuju Aksi. Jurnal Fokus Konseling, 1(2), 93-106.

${ }^{5}$ Putra, A. R. B. (2015). Peran Guru Bimbingan dan Konseling dalam Mengatasi Kecenderungan Perilaku Agresif Peserta Didik di SMKN 2 Palangka Raya tahun pelajaran 2014/2015. Jurnal konseling gusjigang, 1(2).
} 
memperbaikinya. ${ }^{6}$

\section{Pendekatan Preventif}

Adalah usaha bimbingan dan konseling yang di arahkan untuk mengantisipasi berbagai persoalan umum dan mencoba mencegah supaya tidak sampai terjadi kepada individu ${ }^{7}$. Guru bimbingan berupaya memberi pengetahuan dan keterampilan untuk menghindari masalah terebut.

4. Pendekatan Perkembangan

Pelayanan bimbingan dan konseling yang berkembang saat ini adalah Bimbingan dan Konseling Perkembangan (development caunseling fokus pelayanan bimbingan dan konseling kepada pencegahan dan pengembangan.karena tujuan utama pelayanan bimbingan dan konseling adalah perkembangan optimal dan strategi utama usaha bimbingan ${ }^{8}$.

\section{Penutup}

Dari pembahasan diatas dapat disimpulkan bahwa pendekatan memiliki beberapa fungsi yang memengaruhi tingkat pengetahuan guru terhadap peserta didik. Selain itu, pendekatan juga terbagi menjadi 4 macam yaitu:

1. Pendekatan kritis

2. Pendekatan remidial

3. Pendekatan preventif

4. Pendekatan perkembangan

\footnotetext{
${ }^{6}$ Sainuddin, I. H., \& Wekke, I. S. (2020). Syekh Yusuf Al-Makassari: Pandangan Etika dan Filsafat. ${ }^{7}$ Sainuddin, I. H. Dakwah di Era Sosial Media.

${ }^{8}$ Handaka, I. B., \& Maulana, C. (2017). Peran Guru Bimbingan Dan Konseling Dalam Implementasi Gerakan Literasi Nasional. In Prosiding Seminar Bimbingan Dan Konseling (Vol. 1, No. 1, pp. 227-237).
} 


\section{Daftar Pustaka}

Bhakti, C. P. (2015). Bimbingan Dan Konseling Komprehensif: Dari Paradigma Menuju Aksi. Jurnal Fokus Konseling, 1(2), 93-106.

Bhakti, C. P. (2015). Bimbingan Dan Konseling Komprehensif: Dari Paradigma Menuju Aksi. Jurnal Fokus Konseling, 1(2), 93-106.

Putra, A. R. B. (2015). Peran Guru Bimbingan dan Konseling dalam Mengatasi Kecenderungan Perilaku Agresif Peserta Didik di SMKN 2 Palangka Raya tahun pelajaran 2014/2015. Jurnal konseling gusjigang, 1(2).

Sainuddin, I. H., \& Wekke, I. S. (2020). Syekh Yusuf Al-Makassari: Pandangan Etika dan Filsafat.

Sainuddin, I. H. Dakwah di Era Sosial Media.

Handaka, I. B., \& Maulana, C. (2017). Peran Guru Bimbingan Dan Konseling Dalam

Implementasi Gerakan Literasi Nasional. In Prosiding Seminar Bimbingan Dan Konseling (Vol. 1, No. 1, pp. 227-237). 